\title{
The Implementation of Legislative Electoral Crime Sanctions in South Kalimantan Province
}

\author{
Ahmad Syaufi ${ }^{1^{*}} \quad$ Mursidah $^{2} \quad$ Aurora Fatimatuz Zahra ${ }^{3}$ \\ 1.Criminal Law Lecturer, Faculty of Law Lambung Mangkurat University, Banjarmasin, Kalimantan Selatan, \\ Indonesian \\ 2.Teachers, State Senior High School 8, Banjarmasin, Kalimantan Selatan, Indonesian \\ 3.Student International Program For Law and Sharia (IPOLS), Faculty of Law Muhammadiyah University of \\ Yogyakarta, Bantul, D.I. Yogyakarta, Indonesian
}

\begin{abstract}
The purpose of this research is to find out and analyze the implementation of criminal sanctions for electoral crimes in the 2019 legislative elections in South Kalimantan Province.The research type used is empirical legal research sourced from (1) primary data obtained through interviews; (2) secondary data sourced from the literature and related documents. The results showed that the implementation of criminal sanctions in the 2019 Legislative Elections in the South Kalimantan Province was not yet maximally applied, namely the finding of judges' decisions that gave light sentences in the form of probation that were not in line with the spirit of criminalization in the Election Law and did not provide a deterrent effect. In addition, the existence of disparity in criminal decisions that will have an impact on dissatisfaction for convicts and even the public in general.
\end{abstract}

Keywords: Implementation, Sanctions, Electoral Crime, Legislative

DOI: $10.7176 / \mathrm{JLPG} / 97-04$

Publication date:May $31^{\text {st }} 2020$

\section{Introduction}

The concept of popular sovereignty puts the highest authority in the hands of the people. Based on Pancasila, the aim of the Republic of Indonesia is to establish a just and prosperous society. The State of Indonesia is a state of law with characteristics as a modern state based on democracy and full sovereignty by the people. Elections are a form of people's political participation in a democratic country, so the honesty and fairness of the implementation of elections will be a reflection of the quality of democracy.

The direct implementation of the General Election to elect the representatives of the people in the representative institutions, both Central and Regional in Indonesia is one of the main agenda of the Reformation in the political field in an effort to build and realize a democratic state.

Election (election) is the process of choosing people to fill certain political positions. The General Election System has a mechanism and process of democracy which is a manifestation of people's sovereignty as guaranteed in the constitution. Article 2 paragraph (1) of the 1945 Constitution of the Republic of Indonesia states that sovereignty is in the hands of the people and is carried out according to the Constitution.

The meaning of "sovereignty is in the hands of the people" in this case is that the people have sovereignty, the responsibility of rights and obligations to democratically elect a leader who will form a government to take care and serve all levels of society, and elect representatives of the people to oversee the course of the government.

Article 22E paragraph (6) of the 1945 Constitution of the Republic of Indonesia states that elections to elect members of the People's Legislative Assembly, the Regional Representative Council, and the Regional People's Representative Council are held on the basis of direct, general, free, confidential, honest, and fair. The intended general election is held by guaranteeing the principle of representation, which means that every citizen has a representative sitting in a representative institution that will voice the aspirations of the people at every level of government, from the central to the regions.

The direct principle, the people as voters have the right to vote directly in accordance with the wishes of their conscience. Elections that are general contain meaning that guarantees opportunities that are comprehensive for all citizens, regardless of ethnicity, religion, race, class, gender, ethnicity, occupation, and social status. Every citizen who has the right to vote, is free to make his choice without pressure and coercion from anyone. In exercising their rights, every citizen is guaranteed security by the state, so that they can choose according to their conscience. In voting, voters are guaranteed that their choice will not be known by any party. The Election Organizer and all parties involved in the election implementation process must be honest and act in accordance with the laws and regulations. Likewise, every voter and election participant has the right to receive the same treatment, and is free from fraud by any party.

It is undeniable that in the implementation of General Elections, especially for the election of members of the DPR, DPD and DPRD, there are still many violations occurring, both administrative and violations in the form of criminal acts.

Electoral crime in Indonesia has experienced many changes in its development in the form of an increase in 
the types of criminal acts to differences in the addition of criminal sanctions. This is due to the fact that election criminal acts are increasingly becoming a serious concern because of the success of democratic countries in terms of their success in holding elections. The government then tightened the rule of law regarding elections by further increasing criminal sanctions for the perpetrators. Law Number 7 of 2017 concerning General Elections which forms the basis and reference for the 2019 elections has set the mechanism for handling violations and criminal acts that occur in the implementation of elections. In Law Number 7 of 2017 it has been regulated that there are 4 (four) institutions involved in handling electoral crime cases namely the Election Supervisory Body (Bawaslu), the Police, Attorney's Office and the Court.

To streamline the handling of election violation cases involving criminal offenses, Bawaslu, the Police, and the Prosecutor's Office established an Integrated Law Enforcement Center (Sentra Gakkumdu), the legal umbrella is a joint understanding between the Attorney General of the Republic of Indonesia, the Chief of the Indonesian Police and the Chairperson of the Election Supervisory Board.

The membership of the Gakkumdu Center at the central level consists of the Police Kabareskrim, the Deputy Attorney General for General Crimes and the Chairperson of the Election Supervisory Election Bawaslu. At the provincial level consists of the Director of Criminal / General Affairs, the Assistant of the General Criminal Prosecutor, the Coordinator of the Legal Affairs and Handling of Election Violations in the Provincial Bawaslu, and at the district / city level the members are the Head of the Criminal Investigation Unit, the Head of the General Criminal Section and the Coordinator of the Legal Affairs and Handling of Election Violations Bawaslu Regency / City.

Law enforcement in an electoral crime is very important in order to embody a clean, honest and fair election (free and fair election).

Various violations that can be categorized as election offenses occur throughout the stages of the implementation of the General Election. These violations are not only committed by election participants, in this case political parties and / or candidates for legislative members, but also by election organizers at various levels.

In the 2019 legislative elections in South Kalimantan Province, there were 6 (six) Electoral criminal cases handled by Gakkumdu. Responding to these criminal acts, the Election Supervisory Body (Bawaslu) and Gakkumdu have an important role in the law enforcement process related to electoral criminal acts that occur. Based on data obtained from the Gakkumdu Province of South Kalimantan, criminal cases that occurred in the 2019 legislative elections are as follows:

Table 1. Election Criminal Act Legislative 2019 in South Kalimantan Province

\begin{tabular}{|c|l|c|}
\hline No & \multicolumn{1}{|c|}{ City/District } & Number of Cases \\
\hline 1 & Banjarmasin & 2 \\
\hline 2 & Banjarbaru & 2 \\
\hline 3 & Banjar & - \\
\hline 4 & Barito Kuala & - \\
\hline 5 & Tapin & - \\
\hline 6 & South Hulu Sungai & - \\
\hline 7 & West Hulu Sungai & -- \\
\hline 8 & North Hulu Sungai & - \\
\hline 9 & Balangan & - \\
\hline 10 & Tabalong & - \\
\hline 11 & Tanah Laut & - \\
\hline 12 & Kotabaru & 6 \\
\hline 13 & Tanah Bumbu & - \\
\hline & \multicolumn{2}{|c|}{ Total } \\
\hline
\end{tabular}

Source: South Kalimantan Gakkumdu, 2019

Settlement of electoral crime according to statutory regulations is carried out with a criminal justice mechanism and system. Settlement outside this system is against the law because it does not comply with applicable laws and regulations. Electoral crime is seen as a prohibited act that is serious and must be resolved in a short time, in order to achieve the objectives of criminal provisions to protect the democratic process through elections.

\section{Research Problems}

Based on the background of the problem above, the problem is summarized as follows; How is the implementation of criminal sanctions for electoral crime in the 2019 legislative elections in South Kalimantan Province?

\section{Research Methods}

This type of research is empirical legal research, which focuses on field research to get primary data. In addition, 
library research is needed that serves to complement and support the data obtained in the field. The place of research chosen to obtain data is the Gakumdu Center of South Kalimantan Province. Primary Data, which is data obtained directly at the research site from the results of direct interviews with the problem, namely the Team assigned to the Gakkumdu Center in South Kalimantan Province. Secondary data, i.e. data obtained through documents and archives provided by the parties involved in this research, and library research materials both by collecting techniques and inventorying books, scientific works, articles articles from the internet, as well as documents related to the problem under study.

To process primary and secondary data as described above, in order to become an integrated and systematic research work, an analytical technique known as Descriptive Juridical analysis is needed, which is to harmonize and describe the real situation regarding the implementation of criminal sanctions against election offenders the 2019 legislature in South Kalimantan Province. Then based on the results of interviews and literature studies obtained, the data is then processed and analyzed qualitatively to produce descriptive data. This is intended to obtain discussions and conclusions that are relevant, appropriate, and in accordance with the problem under study.

\section{Result and Discussion}

In the field of criminal law, the term "crime" is a very important part because the various issues that arise in criminal law are always linked to the issue of crime.

Some of the other terms that can be found besides the terms of crime are criminal events, criminal acts and delicacies, which basically have the same meaning, all of which are translations of the term "strafbaar feit".

Lawmakers themselves use the term strafbaar feit to refer to what is known as a crime in the Criminal Law Book, without giving a clue as to what the term strafbaar actually means.

In Dutch, "feit" means part of a statement, while "strafbaar" means punishable, so if the term strafbaar feit literally translates to: "Some part of a sentence that can be punished", of course this meaning does not to be precise, because in the future we will be able to see that what is punishable is essentially human, so it is not a fact, an act." (Lamintang 1984)

According to Hazewinkel-S Storm in his book "Heileding tot de studie van het Nederlands Strafrecht", the crime is: "As a human behavior that at one point was rejected in a behavior that should be suppressed by criminal law by using means of a nature forcing what is in it" (Lamintang 1984).

Simon in his book "Leerbook van het Nederlandsc Strafrecht", sums up the crime: "as an unlawful act committed by a person who is responsible or unintentional by a person who is liable for an act and which by law has been construed as a criminal act. punished" (Lamintang 1984).

Further H. B. Vos in his book "Leerbook van Nederlands Strafrecht" states the term crime is: "a human act that is threatened by the rule of law, so a behavior that is generally prohibited by criminal threats" (Poernomo 1985)

Van Hamel in his book "Inleiding" has formulated the strafbaar feit as "an attack or threat to the rights of others" (Poernomo 1985).

While Pompe in his book entitled "Hand Book" states that: "The words strafbaar feit theoretically can be formulated as a violation of norms (interference with the rule of law) which has been accidentally carried out by an offender, where the sentence imposed on the offender is for the sake of preserving order the law and its translation in the public interest" (Lamintang 1984).

Furthermore, Pompe stated that "according to our positive law, a strafbaar feit is actually nothing but action which according to the formulation of the law which states that an action can be punished" (Lamintang 1984).

While Moeljatno (1987) provides a definition of a criminal offense, namely: "acts that are prohibited by a rule of law, which prohibitions are accompanied by threats (sanctions) in the form of certain crimes, for those who violate these acts".

Then Wirjono Prodjodikoro (1991) provided the definition of a criminal act, that "a criminal act means an act in which the perpetrator may be subject to criminal penalties. And these perpetrators can be called as a subject of a crime ".

In addition, R. Soesilo (1979) stated that "a criminal offense is an act that violates or is contrary to the law which is carried out in error by a person who can be accounted for".

The elements contained in a criminal offense, according to P. A. Lamintang (1984), are divided into:

1. Subjective elements, i.e. elements that are inherent in the person of the offender or which are related to the person of the offender, and include everything contained in his heart, consisting of:
a. intentional or accidental;
b. the intent of an experiment;
c. various purposes or oogmark;
d. plan in advance;
e. fear.

2. Objective elements, i.e. elements that related to conditions, that is, in situations where the actions of the agent must be carried out, consisting of: 

a. illegitimacy;
b. the quality of the agent;
c. causality.

Next to the elements of the crime, E.Y. Kanter and S.R. Sianturi (2002) (Tresna 1959) summarize it into some elements:

1. Subject

2. Error

3. Is against the law (from action)

4. An act that is prohibited or required by law / rules and the offender is threatened with crime

5. Time, place and circumstances (other objective elements).

Based on the description above, it can be formulated that the definition of a crime, as follows: an action at a certain place, time and condition, which is prohibited or required and threatened with crime by law, is against the law and with errors by someone (who is capable of being responsible.

The Law Number 7 of 2017 concerning Elections does not explain in detail what constitutes the electoral crime. The definition of election criminal offenses can be found in the literature.

According to Djoko Prakoso (1987), that "electoral crime offenders are any person or legal entity or organization that intentionally violates the law, disrupts obstructs or interferes with the general election held according to the law".

This definition put forward by Djoko Prakoso is very simple, because if we consider several criminal provisions in the Election Law, the act of confusing, obstructing or interfering with the general election is only part of the electoral crime. The scope of electoral crime is indeed very broad in scope. Includes all criminal offenses that occur in the process of organizing elections, including ordinary criminal acts during campaigning or financial administration that occurs in tenders for the purchase of election equipment.

Topo Santoso (2006) provides a definition of electoral crime in three forms including:

1. All criminal offenses related to the holding of elections which are regulated in the Election Law.

2. All criminal offenses relating to the holding of elections (for example in Political Party Law or in the Criminal Code).

3. All criminal offenses that occur during elections (including traffic violations, violent persecution, destruction) and so on.

The first understanding is the narrowest definition of the three definitions above, but at the same time the strictest and focused understanding, that is only refer to the criminal act regulated in the Election Law. With such coverage, people will easily look for electoral crime, namely in the Election Law.

Responding to the two definitions above, Dedi Mulyadi (2012) redefined the electoral crime, the definition of electoral crime into two categories:

1. Special election criminal offenses are all criminal offenses related to the election and are carried out at the stage of the election administration which is regulated in the Election Law.

2. General election criminal acts are all criminal acts related to the election and are carried out at the stage of organizing the election as well as in the Election Law and the settlement is beyond the election stage through the General Court

The choice of a democratic system in Indonesia, requires the existence of political parties as an extension of the people to deliver their aspirations in the general election must get its own place in this country. Political parties are an absolute prerequisite for a country that adheres to a democratic system. Democracy and political parties in a democracy are like two sides of a coin, which cannot be separated from one another. Because elections are a form of people's political participation in a democratic country, cleanliness, honesty and fairness in the implementation of general elections which will reflect the quality of democracy in the country concerned. This is in line with the provisions of Article 1 number 1 of Law Number 7 of 2017 concerning General Elections, stating that General Election, hereinafter referred to as Election, is a means of popular sovereignty to elect members of the People's Legislative Assembly, members of the Regional Representative Council, the President and Vice President, and members of the Regional People's Representative Council, which is carried out directly, publicly, freely, confidentially, honestly and fairly in the Unitary State of the Republic of Indonesia based on Pancasila and the 1945 Constitution of the Republic of Indonesia.

Indonesia from the beginning has had regulations regarding elections. This shows that how elections are very important in the life of the state in Indonesia. However, this ideal condition does not seem to run smoothly without anomalies or phenomena that injure the idealistic values of the General Election, from the very beginning to the last General Election, there have always been violations of Election norms. Cases that often occur in every election are cases of inflated votes and / or money politics or other forms of election violations. Voting or money politics and other forms of election violations can be categorized as criminal acts. Electoral crime is a crime related to the administration of elections which are regulated in the Election Law.

Electoral crime in Indonesia has experienced several developments including the broader scope of electoral 
criminal, an increase in the types of electoral crime, and an increase in criminal sanctions.

Settlement of election criminal acts is carried out in accordance with applicable laws and regulations, which places the Police as the frontline to conduct inquiries and investigations, subsequently the Prosecutor's Office to carry out prosecutions, and the Court to adjudicate cases, and so on according to criminal proceedings as regulated in the Code of Law Criminal Procedure Law (KUHAP). Thus, the resolution of electoral crimes according to existing laws and regulations takes place in the criminal justice system. Settlement outside this system is against the law because it does not comply with applicable laws and regulations. However, if seen from the settlement of electoral crime cases that have existed so far, not many cases can reach the Court level. Efforts to uphold the law against Election criminal acts are as a way to achieve honest and fair elections conducted using criminal law, in the form of imprisonment and confinement / fines. The use of criminal sanctions as an instrument of law enforcement is the application of criminal law in an effort to overcome crime as part of legal politics.

Electoral crime is seen as a prohibited act that is serious in nature and must be resolved in a short time, in order to achieve the goal of establishing criminal provisions to protect the democratic process through elections.

Table 2. The Implementation of Criminal Sanction to The Electoral Crime on The Legislative 2019 in South

Kalimantan Province

\begin{tabular}{|c|c|c|c|c|c|c|}
\hline \multirow[t]{2}{*}{ No } & \multirow[t]{2}{*}{ Offender } & \multirow[t]{2}{*}{ Article } & \multicolumn{2}{|c|}{ Decision Number } & \multirow[t]{2}{*}{ Threat } & \multirow[t]{2}{*}{ Punishment } \\
\hline & & & District Court & High Court & & \\
\hline 1 & $\begin{array}{l}\text { Anang } \\
\text { Misran } \\
\text { Hidayatullah }\end{array}$ & $\begin{array}{l}\text { Article } 520 \\
\text { Law Number } \\
7 \text { Year } 2017\end{array}$ & $\begin{array}{l}\text { 968/Pid.Sus/2018/PN } \\
\text { Bjm }\end{array}$ & 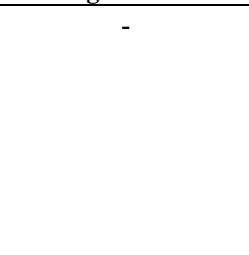 & $\begin{array}{l}\text { A maximum of } 6 \\
\text { years imprisonment } \\
\text { and a maximum fine } \\
\text { of Rp. } \\
72,000,000.00\end{array}$ & $\begin{array}{l}\text { Criminal } \\
\text { imprisonment for } 2 \\
\text { months and a fine of } \\
\text { Rp. 2,000,000.00 / } \\
\text { subsidiary criminal } \\
\text { imprisonment for } 1 \\
\text { month }\end{array}$ \\
\hline 2 & Rizali Hadi & $\begin{array}{l}\text { Article } 521 \\
\text { jo. Article } \\
280 \\
\text { paragraph (1) } \\
\text { of letter h of } \\
\text { Law No. } 7 \text { of } \\
2017\end{array}$ & $\begin{array}{l}\text { 21/Pid.Sus/2019/PN } \\
\text { Bjb }\end{array}$ & $\begin{array}{c}\text { 21/Pid.Sus/2019/PT } \\
\text { BJM }\end{array}$ & $\begin{array}{l}\text { The maximum } \\
\text { imprisonment of } 2 \\
\text { years and a } \\
\text { maximum fine of } \\
\text { Rp. } 24,000,000.00\end{array}$ & $\begin{array}{l}\text { Criminal } \\
\text { imprisonment for } 6 \\
\text { months and a fine of } \\
\text { Rp. } 3,000,000.00 \\
\text { / confinement criminal } \\
\text { subsidiary } 1 \\
\text { Criminal months do } \\
\text { not need to be served } \\
\text { with a probation } \\
\text { period of } 1 \text { year }\end{array}$ \\
\hline 3 & $\begin{array}{l}\text { Nurdin, } \\
\text { S.PD.I }\end{array}$ & $\begin{array}{l}\text { Article } 521 \\
\text { jo. Article } \\
280 \\
\text { paragraph (1) } \\
\text { of the letter } \mathrm{h} \\
\text { Law No. } 7 \text { of } \\
2017 \text { jo. } \\
\text { Article } 55 \\
\text { paragraph (1) } \\
\text { to } 1 \text { of the } \\
\text { Penal Code }\end{array}$ & $\begin{array}{l}\text { 20/Pid.Sus/2019/PN } \\
\text { Bjb }\end{array}$ & $\begin{array}{c}\text { 20/Pid.Sus/2019/PT } \\
\text { BJM }\end{array}$ & $\begin{array}{l}\text { The maximum } \\
\text { imprisonment of } 2 \\
\text { years and a } \\
\text { maximum fine of } \\
\text { Rp. } 24,000,000.00\end{array}$ & $\begin{array}{l}\text { Criminal } \\
\text { imprisonment for } 6 \\
\text { months and a fine of } \\
\text { Rp. 3,000,000.00 / } \\
\text { subsidiary criminal } \\
\text { imprisonment for } 1 \\
\text { month } \\
\text { Prison sentences do } \\
\text { not need to be served } \\
\text { with a } 6 \text { month } \\
\text { probation }\end{array}$ \\
\hline 4 & Drs. Fikri & $\begin{array}{l}\text { Article } 520 \text { of } \\
\text { Law Number } \\
7 \text { of } 2017\end{array}$ & $\begin{array}{l}\text { 568/Pid.Sus/2019/PN } \\
\text { Bjm }\end{array}$ & $\begin{array}{c}\text { 81/Pid.Sus/2019/PT } \\
\text { BJM }\end{array}$ & $\begin{array}{l}\text { A maximum of } 6 \\
\text { years imprisonment } \\
\text { and a maximum fine } \\
\text { of } \mathrm{Rp} \text {. } \\
72,000,000.00\end{array}$ & $\begin{array}{l}\text { Criminal } \\
\text { imprisonment for } 3 \\
\text { months and a fine of } \\
\text { Rp. 5,000,000.00 / } \\
\text { subsidiary criminal } \\
\text { imprisonment for } 2 \\
\text { months } \\
\text { Prison sentences do } \\
\text { not need to be served } \\
\text { with a } 6 \text { month } \\
\text { probation }\end{array}$ \\
\hline
\end{tabular}




\begin{tabular}{|c|c|c|c|c|c|c|}
\hline \multirow[t]{2}{*}{ No } & \multirow[t]{2}{*}{ Offender } & \multirow[t]{2}{*}{ Article } & \multicolumn{2}{|c|}{ Decision Number } & \multirow[t]{2}{*}{ Threat } & \multirow[t]{2}{*}{ Punishment } \\
\hline & & & District Court & High Court & & \\
\hline 5 & $\begin{array}{l}\text { Riswan } \\
\text { Ihwani Als. } \\
\text { IWAN }\end{array}$ & $\begin{array}{l}\text { Article } 532 \text { jo } \\
554 \text { Law No. } \\
7 \text { of } 2017 \text { Jo } \\
\text { Article } 55 \text { of } \\
\text { the Penal } \\
\text { Code }\end{array}$ & $\begin{array}{l}\text { 187/Pid.Sus/ } \\
\text { 2019/PN Mtp }\end{array}$ & $\begin{array}{l}\text { 102/Pid.Sus/ } \\
\text { 2019/PT BJM }\end{array}$ & $\begin{array}{l}\text { The maximum } \\
\text { imprisonment of } 4 \\
\text { years and a } \\
\text { maximum fine of } \\
\text { Rp. 48,000,000.00 }\end{array}$ & $\begin{array}{l}\text { Criminal Prison for } 2 \\
\text { months and a fine of } \\
\text { Rp. } 1,000,000 \\
\text { subsidiary criminal } \\
\text { imprisonment for } 1 \\
\text { month } \\
\text { Prison sentences do } \\
\text { not need to be served } \\
\text { with a } 6 \text { month } \\
\text { probation }\end{array}$ \\
\hline 6 & $\begin{array}{l}\text { Gusti } \\
\text { Irhamni Als } \\
\text { IIR, Heri } \\
\text { Kusnadi, } \\
\text { Muhammad } \\
\text { Marzuki, } \\
\text { Salapudin } \\
\text { Als Udin }\end{array}$ & $\begin{array}{l}\text { Article } 505 \text { of } \\
\text { Law Number } \\
7 \text { of } 2017 \\
\text { concerning } \\
\text { General } \\
\text { Elections, Jo } \\
\text { Article } 55 \text { of } \\
\text { the Criminal } \\
\text { Code }\end{array}$ & $\begin{array}{l}\text { 188/ } \\
\text { Pid.Sus/2019/PN } \\
\text { Mtp }\end{array}$ & $\begin{array}{c}\text { 103/Pid.Sus/2019/PT } \\
\text { BJM }\end{array}$ & $\begin{array}{l}\text { The maximum } \\
\text { confinement penalty } \\
\text { is } 1 \text { year and the } \\
\text { maximum fine is } \mathrm{Rp} \text {. } \\
12,000,000.00\end{array}$ & $\begin{array}{l}\text { Criminal confinement } \\
\text { for } 2 \text { months and a fine } \\
\text { of Rp. } 1,000,000 \text { / } \\
\text { subsidiary criminal } \\
\text { imprisonment for } 1 \\
\text { month } \\
\text { Prison sentences do } \\
\text { not need to be served } \\
\text { with a } 6 \text { month } \\
\text { probation }\end{array}$ \\
\hline
\end{tabular}

Source: Research Results, 2019

The data as illustrated in table II above shows that criminal sanctions or sentences imposed by the judges at the District Court and the High Court against perpetrators proven to have committed more electoral crime ordered sentences with probation, only one case of the perpretator is serving a sentence, namely Anang Misran Hidayatullah.

Judges' verdicts convicting the perpetrators of electoral crimes containing sentence orders with probation become a trend in criminal cases in the legislative election in 2019 in South Kalimantan Province. The probation seems to be merely trying to teach the offender without having to make the offender languish in prison. The question is how in terms of the deterrent effect?

Sentences or probation (voorwaardelijke) in the concept of punishment are indeed possible to apply to defendants who are sentenced to a maximum of 1year imprisonment. This provision can be seen in Article 14 a paragraph (1) of the Criminal Code which states:

If the judge gives a maximum sentence of one year or a sentence of imprisonment, does not include a substitute imprisonment, then in his decision the judge can also order that the criminal does not have to be served, unless there is a judge's decision that determines otherwise, because the convicted person committed a criminal act before the probation period specified in the above command expires, or because the convicted person during the probation period does not fulfill the special conditions that may be specified otherwise in the order.

This means that even if the defendant is found guilty and sentenced to imprisonment, there is no need to be imprisoned or correctional institutions as long as the trial period can improve his behavior. This is motivated by thoughts that want to give opportunity to criminal offenders to improve their behavior in society. In addition to that it removes the impression of the severity of criminal penalties and the existence of revenge. Likewise, with fines, philosophically interpreted as a pastor. Not to compensate, enrich the country or impoverish actors.

Based on the data, cases of electoral crime in the 2019 legislative elections in South Kalimantan Province, the sentence imposed by the judge included a sentence of 2 months in prison and a sentence of between 2 months to 6 months in prison so that the conditions for granting probation were fulfilled.

Trial verdicts (light) became the trend of choice of judges in deciding electoral crime cases. How long is a suspended sentence, as well as the size of the fine only the judge who fully knows the reason for the decision. The problem is that light sentences in the form of such trials are given to many election criminal cases which carry a sentence of more than 1 year. For example, in a criminal case of forgery of documents which threatens a sentence of 6 years in prison and a fine of Rp. 72 million, using education facilities that threaten a sentence of 2 years in prison and a fine of Rp. 24 million, and ballooning which threatens a sentence of 4 years in prison and a fine of Rp. 48 million.

Light sentences were common among them because the verdict of the panel of judges did not meet the prosecutors' demands, as in the following table. 


\begin{tabular}{|c|c|c|c|}
\hline No & Offender & Charge & Verdict \\
\hline 1 & $\begin{array}{l}\text { Anang Misran } \\
\text { Hidayatullah }\end{array}$ & $\begin{array}{l}\text { Criminal imprisonment for } 3 \\
\text { months and a fine of Rp. } \\
3,000,000.00 \text { / subsidiary criminal } \\
\text { imprisonment for } 2 \text { months }\end{array}$ & $\begin{array}{l}\text { Criminal imprisonment for } 2 \text { months and a } \\
\text { fine of Rp. 2,000,000.00 / subsidiary } \\
\text { criminal imprisonment for } 1 \text { month }\end{array}$ \\
\hline 2 & Rizali Hadi & $\begin{array}{l}\text { Criminal imprisonment for } 3 \\
\text { months and a fine of Rp. } \\
3,000,000.00 \text { / subsidiary criminal } \\
\text { imprisonment for } 1 \text { month }\end{array}$ & $\begin{array}{l}\text { Criminal imprisonment for } 6 \text { months and a } \\
\text { fine of Rp. 3,000,000.00/ subsidiary } \\
\text { criminal imprisonment for } 1 \text { month } \\
\text { Trial period of } 1 \text { year }\end{array}$ \\
\hline 3 & Nurdin, S.PD.I & $\begin{array}{l}\text { Criminal imprisonment for } 3 \\
\text { months and a fine of Rp. } \\
3,000,000.00 \text { / subsidiary criminal } \\
\text { imprisonment for } 1 \text { month }\end{array}$ & $\begin{array}{l}\text { Criminal imprisonment for } 6 \text { months and a } \\
\text { fine of Rp. 3,000,000.00/ subsidiary } \\
\text { criminal imprisonment for } 1 \text { month } \\
\text { Trial period of } 6 \text { months }\end{array}$ \\
\hline 4 & Drs. Fikri & $\begin{array}{l}\text { Criminal imprisonment for } 3 \\
\text { months and a fine of Rp. } \\
10,000,000.00 \text { / subsidiary } \\
\text { criminal imprisonment for } 2 \\
\text { months }\end{array}$ & $\begin{array}{l}\text { Criminal imprisonment for } 3 \text { months and a } \\
\text { fine of Rp. 5,000,000.00/ subsidiary } \\
\text { criminal imprisonment for } 2 \text { months } \\
\text { Trial period of } 6 \text { months }\end{array}$ \\
\hline 5 & $\begin{array}{l}\text { Riswan Ihwani Als. } \\
\text { IWAN }\end{array}$ & $\begin{array}{l}\text { Criminal imprisonment for } 2 \\
\text { months with an order that the } \\
\text { accused immediately detained and } \\
\text { a fine of } \mathrm{Rp} \text {. } 1,000,000.00 / \\
\text { subsidiary criminal imprisonment } \\
\text { for } 1 \text { month }\end{array}$ & $\begin{array}{l}\text { Criminal Prison for } 2 \text { months and a fine of } \\
\text { Rp. } 1,000,000 / \text { subsidiary criminal } \\
\text { imprisonment for } 1 \text { month } \\
\text { Trial period of } 6 \text { months }\end{array}$ \\
\hline 6 & $\begin{array}{l}\text { Gusti Irhamni Als } \\
\text { IIR, Heri Kusnadi, } \\
\text { Muhammad } \\
\text { Marzuki, Salapudin } \\
\text { Als Udin }\end{array}$ & $\begin{array}{l}\text { Criminal detention for } 2 \text { months } \\
\text { each with an order that the } \\
\text { defendants be detained } \\
\text { immediately and a fine of Rp. } \\
1,000,000.00 \text { / subsidiary criminal } \\
\text { imprisonment for } 1 \text { month }\end{array}$ & $\begin{array}{l}\text { Criminal confinement for } 2 \text { months and a } \\
\text { fine of Rp. } 1,000,000 / \text { subsidiary criminal } \\
\text { imprisonment for } 1 \text { month } \\
\text { Trial period of } 6 \text { months }\end{array}$ \\
\hline
\end{tabular}

Source: Research Results, 2019

Based on the data in table III above, the panel of judges agreed in general with the demands of the public prosecutor regarding the length of confinement and imprisonment and fines. However, the panel of judges did not meet the demands of the prosecutor who demanded that the defendant be detained, instead the panel of judges only gave a light sentence in the form of a trial. There are at least 5 cases where the sentence was sentenced to probation, and only 1 case the defendant must serve a prison sentence.

The number of light sentences is certainly not in line with the spirit of criminalization in the Election Law, and does not provide a deterrent effect. Especially, if the perpetrators are candidates and organizers, who are expected to be trusted and follow the rules of the game honestly (fair). The Supreme Court in Circular Letter No. 1 of 2000 concerning Criminal Deviations with Severity and the Nature of Crimes, once asked all judges to "impose a crime that is truly commensurate with the severity and nature of the crime and not to impose a criminal offense that offends justice in society". But in reality in the case of electoral crime, there are still many who are given less than worthy decisions.

In addition, disparities or differences in criminal decisions often bring their own problems in law enforcement. Criminal disparity is the implementation of an unequal criminal act to the same criminal act or to a criminal act in which the nature of the danger can be compared without a clear justification. Disparity does not only occur in the same criminal act, but also in the level of seriousness of a crime, and also in the decisions of judges, both one panel of judges and by different judges for the same case.

Disparity in the decision is also found in the case of election criminal acts in the 2019 legislative elections in South Kalimantan Province, namely in the Banjarmasin District Court Decision Number 968 / Pid.Sus / 2018 / PN Bjm over the defendant Anang Misran Hidayatullah with Banjarmasin District Court Decision Number 568 / Pid. Sus / 2019 / PN Bjm (reinforced by Decision of PT Banjarmasin Number 81 / Pid.Sus / 2019 / PT BJM) for the defendant Drs. Fikri

Banjarmasin District Court Decision Number 968 / Pid.Sus / 2018 / PN Bjm, the defendant Anang Misran Hidayatullah was found guilty of violating Article 520 of Law Number 7 of 2017. The defendant was sentenced to two months in prison and a fine of Rp. 2,000,000.00 / subsidiary criminal imprisonment for 1 month, and the defendant remains in custody.

Banjarmasin District Court Decision Number 568 / Pid.Sus / 2019 / PN Bjm (reinforced by the Decision of 
PT Banjarmasin Number 81 / Pid.Sus / 2019 / PT BJM), the defendant Drs. Fikri was found guilty of violating Article 520 of Law Number 7 of 2017. The defendant was sentenced to three months in prison and a fine of Rp. $5,000,000.00$ / subside imprisonment for 2 months, and imprisonment does not need to be served with a probation period of 6 months.

Based on the data above, there has been an unequal implementation of criminal acts against the same crime, namely violating Article 520 of Law Number 7 of 2017 without a clear justification. Disparity does not only occur in the same criminal act, but also in the level of seriousness and a criminal offense, and also in the decisions of judges, both one panel of judges and by different judges for the same case.

Seeing the case of the difference in the election criminal verdict, certainly felt that there was something unfair. Although the disparity is a form of the discretion of judges in passing verdicts, on the other hand the different electoral crime decisions can bring dissatisfaction to the convicts and even the public in general. Could it be a question whether the judge has really carried out his duty to uphold law and justice in election criminal cases? Sociologically, the disparity in election criminal decisions is a form of lack of justice (societal justice). Unfortunately, from a formal juridical standpoint such conditions cannot be considered unlawful.

The implementation of criminal sanctions in the 2019 Legislative Elections in South Kalimantan Province out of 6 (six) cases there were 1 (one) case of the defendant serving a prison sentence, 6 (six) cases were subjected to probation, and the discovery of the decision disparity. This situation has shown the existence of paradigm differences among judges in viewing election criminal cases. On the one hand, most judges considered that the conviction (straafinaad), including the conviction of election cases, was not an arena of revenge, so in this view the verdict handed down was more of a corrective step and guidance for the perpetrators. On the other hand, the judges considered the election criminal act in a deeper paradigm, that the election criminal act had injured the sense of justice of the community and damaged the democratic governance system, so that retaliation against the electoral crime had to be prioritized so as to provide a deterrent effect.

\section{Conclusion}

Based on the results of research that has been done, it can be concluded that the implementation of criminal sanctions in the 2019 Legislative Elections in South Kalimantan Province is still not optimally applied, namely the finding of a judge's decision that gives light sentences in the form of probation that is not in line with the spirit of criminalization in the Election Law and does not provide a deterrent effect. In addition, the existence of disparity in criminal decisions that will have an impact on dissatisfaction for convicts and even the public in general.

\section{Suggestion}

Judges should be sentenced in referring to the spirit of criminalization in the Election Law and give a deterrent effect to the perpetrators, and strive to avoid disparity in the decision.

\section{References}

Andrisman, Tri. (2009). Asas-Asas dan Dasar Aturan Hukum Pidana Indonesia. Bandar Lampung: Unila. Chazawi, Adami. (2011). Pelajaran Hukum Pidana I. Jakarta: Raja Grafindo Persada.

Kanter. E.Y. dan S.R. Sianturi. (2002) Asas-Asas Hukum Pidana di Indonesia dan Penerapannya. Jakarta: Storia Grafika, 208-209.

Lamintang, P.A.F. (1984). Dasar-Dasar Hukum Pidana Indonesia. Bandung: Sinar Baru, 172-193.

Moeljatno. (1987) Asas-Asas Hukum Pidana. Jakarta: Bina Aksara, 54.

Muladi. (2008). Lembaga Pidana Bersyarat. Bandung: Alumni.

Mulyadi, Dedi. (2012). Kebijakan Legislasi Tentang Sanksi Pidana Pemilu Legislatif Di Indonesia Dalam Perspektif Indonesia. Jakarta: Gramata Publishing, 418.

Poernomo, Bambang. (1985). Asas-Asas Hukum Pidana. Jakarta: Ghalia Indonesia, 91.

Prakoso, Joko. (1987). Tindak Pidana Pemilu. Jakarta: Sinar Hatapan, Jakarta, 148.

Prodjodikoro, Wirjono. (1991). Asas-Asas Hukum Pidana Di Indonesia. Jakarta-Bandung: Eresco, 50.

Santoso, Topo. (2006). Tindak Pidana Pemilu. Jakarta: Sinar Grafika,11.

Soesilo, R. (1979). Pokok-Pokok Hukum Pidana, Peraturan Umum dan Delik-Delik Khusus. Bogor: Politea, 26.

Tresna, R. (1959). Asas-asas Hukum Pidana. Jakarta: PT. Tiara Limited, 27. 